\title{
Physical processes and the ecology of a winter dinoflagellate bloom of Katodinium rotundatum
}

\author{
R. R. H. Cohen \\ U.S. Geological Survey, Mail Stop 430, Reston, Virginia 22092, USA
}

\begin{abstract}
A red tide of Katodinium rotundatum (Lohmann) (chlorophyll a $>200 \mu \mathrm{g} \mathrm{l}^{-1}$ ) was observed from December 1979 through March 1980 in the Potomac Estuary, Maryland. The bloom began at a water column temperature of $6^{\circ} \mathrm{C}$ and was largest at 4 to $6^{\circ} \mathrm{C}$. K. rotundatum appeared only when the water column was stratified (Dec 1979 through Mar 1980 and 2 wk in Mar 1981). High discharge of fresh water (mean $=463 \mathrm{~m}^{3} \mathrm{~s}^{-1}$ ) in the fall of 1979 induced the density stratification. A $K$. rotundatum bloom in January 1978, reported by other researchers, was also associated with a stratified water column and high fresh-water discharge $\left(299 \mathrm{~m}^{3} \mathrm{~s}^{-1}\right)$. Resting stages of $K$. rotundatum in the benthic sediment may have been the source of the bloom. The bloom was bounded by the freshbrackish water interface and by a salinity of $14 \mathrm{ppt}$. $K$. rotundatum demonstrated positive phototaxis and those trapped below the pycnocline were shade-adapted. There was a diel periodicity in cellular chlorophyll content. No bloom appeared in the winter of 1980-81, diatoms were dominant, and watercolumn stratification was observed only in mid-March 1981 Fresh-water discharge was low late in $1980\left(107 \mathrm{~m}^{3} \mathrm{~s}^{-1}\right)$. Diatoms such as Chaetoceros spp. were dominant only when there was no stratification in the winter of $1980-81$ and at salinities $>14 \mathrm{ppt}$ in both winters. It may be possible to predict future blooms with summer-through-fall discharge data.
\end{abstract}

\section{INTRODUCTION}

Commercial fishermen and others (Lippson et al. 1978) have often reported winter 'red tides' or 'mahogany waters' in the Potomac Estuary, Maryland. In the winter of 1979-80, U.S. Geological Survey personnel on routine sampling cruises observed a dinoflagellate red tide with high concentrations of chlorophyll a (more than $200 \mathrm{\mu g} \mathrm{l}^{-1}$ ) (Blanchard et al. 1982, Cohen et al. 1984).

Dinoflagellate blooms typically have been associated with summer and early fall, low energy, stratified water columns and frontal systems (e.g. Ryther 1965, Seliger et al. 1975, Margalef 1978, Bowman et al. 1981, Incze \& Yentsch 1981). Logical arguments (Margalef 1978) and data (Bowman et al. 1981) have supported the contention that the condition that gives rise to dinoflagellate blooms - a combination of high nutrient supply and a stable, density-stratified water columnis both transitory and anomalous. Dinoflagellates seem to have structural and physiological properties that permit them to avoid sinking below compensation and critical depths in a calm water column and to use biological and physical transport processes to gain access to nutrients (Steidinger \& Haddad 1981). They can migrate vertically (e.g. Loftus et al. 1972, Throndsen 1973) and adapt to low light intensity (e.g. Prezelin \& Matlick 1980, Rivkin et al. 1982).

In contrast, diatoms, in order to remain in the water column and to gain access to adequate light and nutrients, require a high energy system characterized by high levels of turbulence or advection.

I studied the responses of the Potomac River winter red tide to physical processes to compare it with warmwater dinoflagellate blooms. The dinoflagellates of the 1979-80 winter red tide and the diatom-dominated estuary in the winter of 1980-81 were studied to characterize the phytoplankton adaptive responses to temperature, salinity, and density stratification.

The tidal Potomac River and Estuary, Maryland, extends $187 \mathrm{~km}$ from the fall line (transition from the Piedmont Province to the coastal plain) near Chain Bridge (above Washington, DC) to the Chesapeake Bay (Fig. 1a). The transition zone from fresh to brackish water is usually located between Quantico (river $\mathrm{Km} \mathrm{125.6)}$ and Morgantown (Km 80.4). The estuary discussed in this paper, from Morgantown to Pt. Lookout (Km 6.5), is shown in Fig. $1 \mathrm{~b}$. 

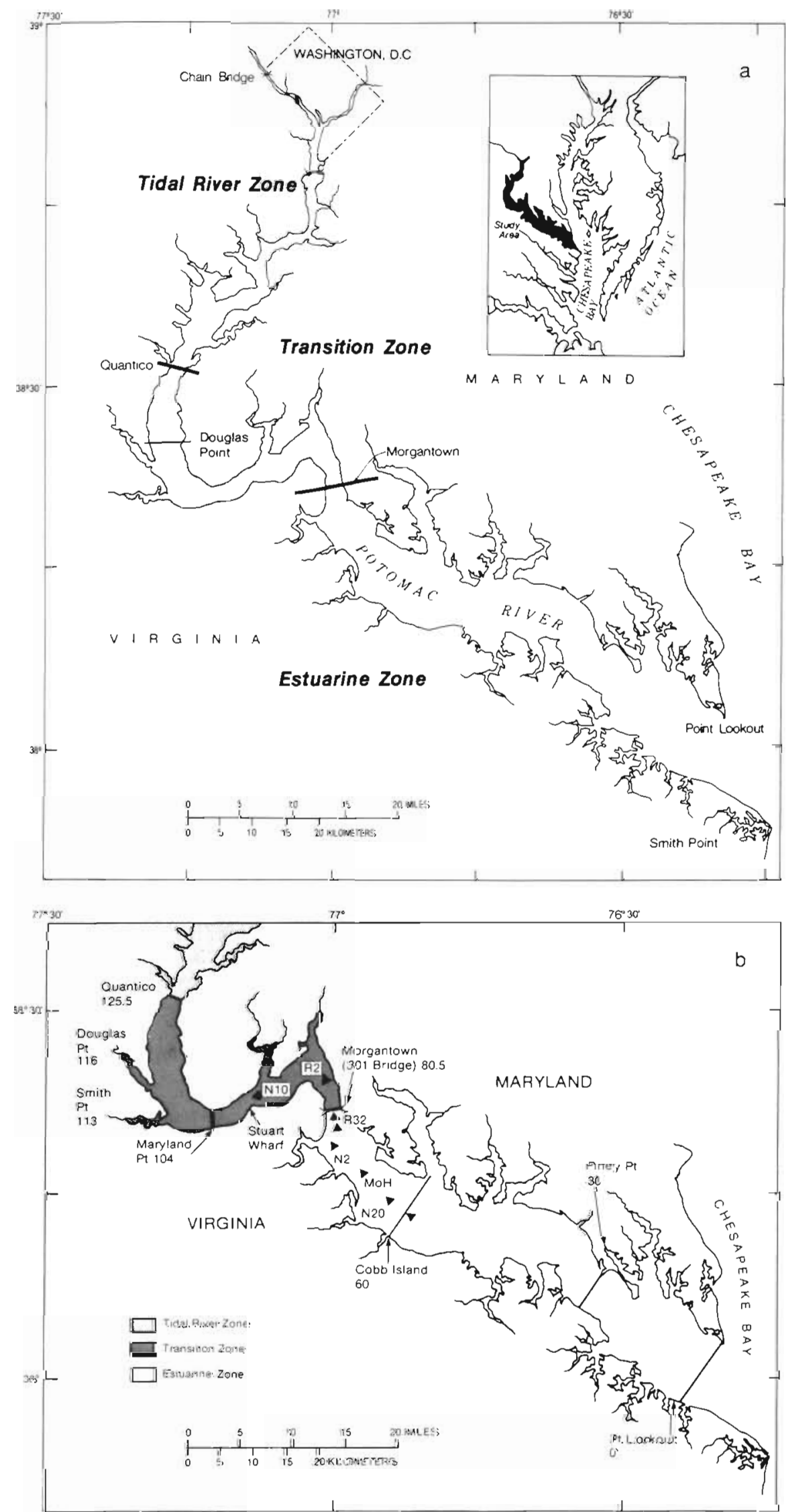

Fig. 1. (a) Map of the Potomac River and Estuary, Maryland. (b) Location of stations at buoys $\mathrm{N} 20, \mathrm{MoH}, \mathrm{N} 2$, R32, R2, N10, and cross-sections at Morgantown (near 301 Bridge), Cobb Island, Piney Point and Point Lookout. N10 is located at the Stuart Wharf cross-section 


\section{METHODS}

The following methods were used in the March 1980 and March 1981 distribution and vertical migration studies. A centrifugal pump and opaque hose were used to collect phytoplankton samples at specific depths at stations Stuart Wharf (Buoy N10, depth $z=8 \mathrm{~m})$, R2 $(z=8 \mathrm{~m}), 301$ Bridge $(z=15 \mathrm{~m})$, Morgantown $(z=20 \mathrm{~m}), \mathrm{R} 32(\mathrm{z}=27 \mathrm{~m}), \mathrm{N} 2(\mathrm{z}=3 \mathrm{~m})$, $\mathrm{MoH}(\mathrm{z}=11 \mathrm{~m})$, Cobb Island $(\mathrm{z}=7 \mathrm{~m})$, Piney Point and, occasionally, other stations between Cobb Island and Point Lookout (Fig. 1b). Fifty $\mathrm{ml}$ of sample were filtered onto glass-fiber filters, extracted in acetone, and analysed fluorometrically for chlorophyll $a$ and phaeophytin $a$ by the Holm-Hansen \& Riemann (1978) modification of the Strickland \& Parsons (1972) method. Samples for phytoplankton identification were fixed with Lugol's Iodine. Phytoplankton were counted and identified using the Utermöhl (1958) method under an inverted microscope as described by Cohen et al. (1984). Water-column temperature, conductivity, and dissolved oxygen were measured with a Hydrolab 4000 series water-quality system. At times, some stations were inaccessible during the intensive March 1980 study (e.g. Station R2 at 1200 h) due to U.S. Navy artillery tests at Dahlgren, Virginia.

Monthly measurements of temperature, conductivity and chlorophyll a were obtained from reports by the interdisciplinary Potomac Estuary Study of the U.S. Geological Survey (Blanchard et al. 1982a, b). Time sequence data of phytoplankton composition is from Cohen et al. (1984).

Benthic sediment was sampled with a Benthos gravity corer at Stations Morgantown, MoH, N20, and in the shallows near the Virginia bank of the Cobb Island transect (Fig. 1b) in July 1983. The depths of the water column were $15,8,10$, and $7 \mathrm{~m}$, respectively. The cores were sectioned every $2 \mathrm{~cm}$ down to $8 \mathrm{~cm}$. One-third of each section was placed in a separate $250 \mathrm{ml}$, cottonstoppered flask. Water of salinity $6 \mathrm{ppt}$ was collected from the estuary at the same time as the cores were taken and was filtered through $0.45 \mu \mathrm{m}$ membrane filters. Each flask was filled with $125 \mathrm{ml}$ of filtered water, placed on a gyratory shaker table, and agitated gently in a reach-in growth chamber. All sediment became oxidized from grey-black to brown in $2 \mathrm{~d}$. The temperature was lowered by approximately 0.5 to $1 \mathrm{C}^{\circ}$ each day, starting at $20^{\circ} \mathrm{C}$ on 20 July. An 8 h light: $16 \mathrm{~h}$ dark cycle was maintained with cool white fluorescent lamps supplying $160 \mu$ Einstein $\mathrm{m}^{-2} \mathrm{~s}^{-1}$. Water samples were collected at $18,12,10,7^{\circ} \mathrm{C}$, and once a week at 4 to $5^{\circ} \mathrm{C}$ and examined for the presence of Katodinium rotundatum. Temperature was maintained between 4 and $5{ }^{\circ} \mathrm{C}$ for the duration of the experiment. Nutrient analyses were performed by the Atlanta Cent- ral Laboratories of the U.S. Geological Survey by standard U.S.G.S. procedures (Skougstad et al. 1979).

The attenuation coefficient for irradiance, $k_{e}$, was estimated using a Secchi disk and by solving the following equation:

$$
\mathrm{k}_{\mathrm{e}}=\frac{1.7}{\mathrm{z}}
$$

where $z=\operatorname{depth}(m)$ of disappearance of Secchi disk.

A ratio of sigma-t near the surface $\left(\sigma_{t}^{5}\right)$ to sigma-t near the bottom $\left(\sigma_{t}^{b}\right)$ was used as a stratification index. The typical equations used to describe vertical stability such as

$$
E=\frac{1}{\varrho} \frac{\delta \varrho}{\delta z} \text { (Neumann \& Pierson 1966) }
$$

where $\mathrm{E}=$ stability index, $\varrho=$ water density, require the use of depth, $z$, in the calculation.

For the discrete case in a very shallow estuary, using $\sigma_{1}$ rather than density:

$$
E=10^{-3} \frac{\left(\sigma_{t}^{b}-\sigma_{t}^{\mathrm{s}}\right)}{\sigma_{\mathrm{t}}^{\mathrm{b}} z}
$$

During periods of stratification, $\sigma_{t}$ varied little below the pycnocline so that it was approximately constant from $7 \mathrm{~m}$ (just below the pycnocline) to $27 \mathrm{~m}$ (the maximum depth for this study). Thus, inclusion of a depth component in the stability equation added no information and gave different stability parameters to sample sites that had otherwise identical stratification characteristics. There are precedents for using ratios with no depth component to calculate stratification parameters (Hansen \& Rattray 1966). The equation for calculating the new stratification parameter (S) becomes

$$
\mathrm{S}=\frac{\sigma_{\mathrm{t}}^{\mathrm{b}}-\sigma_{\mathrm{i}}^{\mathrm{s}}}{\sigma_{\mathrm{t}}^{\mathrm{b}}}
$$

which reduces to

$$
\mathrm{S}=1-\frac{\sigma_{t}^{\mathrm{s}}}{\sigma_{\mathrm{t}}^{\mathrm{b}}}
$$

The ratio on the right side of the equation was used as the stratification parameter and a ratio of 1 indicates a completely mixed system.

\section{RESULTS}

\section{Winter and spring phytoplankton assemblages in 1980 and 1981}

A phytoplankton bloom dominated by the dinoflagellate Katodinium rotundatum appeared in the Potomac Estuary during the winter of 1979-80. Chlorophyll a concentrations often exceeded $200 \mu \mathrm{g} \mathrm{l}^{-1}$ and cell numbers were as high as $17 \times 10^{7} \mathrm{cells}^{-1}$ (Fig. $2 a, b)$. The bloom was sharply delineated upstream by 

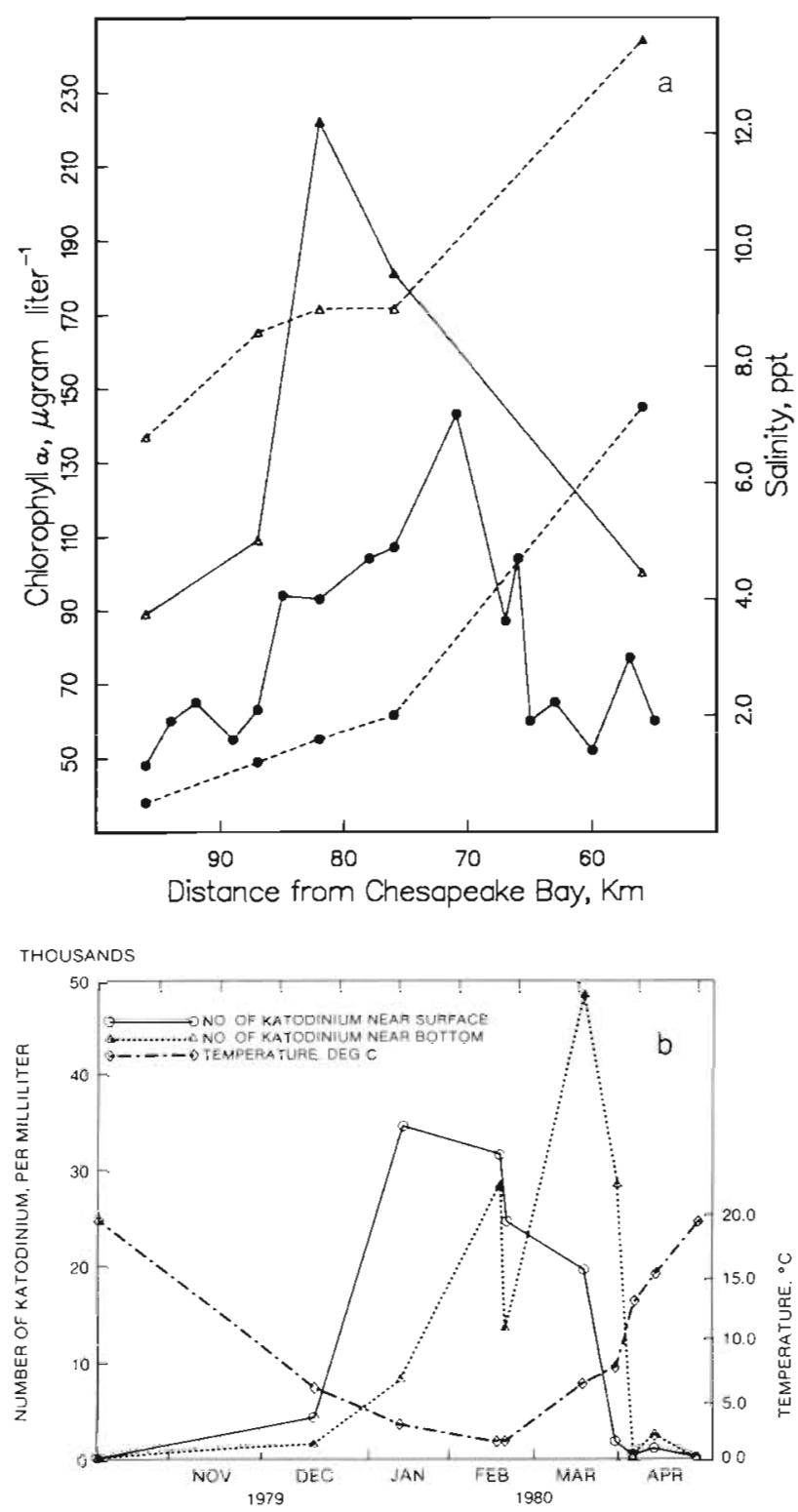

Fig. 2. (a) Distribution of chlorophyll a near the surface $(\bullet-\bullet)$, near the bottom $(\Delta-\Delta)$; conductivity near the surface $(\bullet---)$, near the bottom $(\Delta---\Delta)$ with distance from Chesapeake Bay in March 1980. (b) Katodinium rotundatum. October 1979 to April 1980 Cobb Island distributions of number near the surface $(O)$, near the bottom $(\Delta)$; and temperature $(0)$

the fresh-brackish water front and downstream, near Cobb Island, by surface salinities of 6 ppt and bottom salinities of 13 ppt (Fig. 2a). Bloom conditions began to appear when surface water temperatues were about $6^{\circ} \mathrm{C}$, and cell numbers were highest at 4 to $6^{\circ} \mathrm{C}$ (Fig. 2b). In January and February 1980, numbers were higher above the pycnocline than below (Fig. 2b). They became higher below the pycnocline in March (Fig. 2a, b) and remained so until the bloom dissipated in May.
Cullen et al. (1982) have reported a similar sinking phenomenon for Gymnodinium flavum.

In December 1979, Katodinium rotundatum was predominant along with coccoid green algae (Chlorococcales) and Chroomonas spp. In January 1980, Chroomonasmade up 19 to $38 \%$ of the phytoplankton at Cobb Island ( $\mathrm{Km} \mathrm{60)}$ ). In February 1980, $K$. rotundatum ranged from 43 to $88 \%$ of all phytoplankton between 301 Bridge ( $\mathrm{Km} \mathrm{80.5)}$ and Cobb Island. By March, $K$. rotundatum usually exceeded $50 \%$ of all phytoplankton near the bottom but shared surface dominance with Stephanodiscus spp. Stephanodiscus accounted for 30 to $50 \%$ of the phytoplankton in May. $K$. rotundatum comprised typically $10 \%$ or less of the population at Piney Point (Km 30) throughout the winter of 1980 and was almost never observed downstream of Piney Point.

In contrast to winter 1979-80, chlorophyll a concentrations rarely exceeded $100 \mu \mathrm{g} \mathrm{I}^{-1}$ in winter $1980-81$. The percent composition of Katodinium rotundatum exceeded 50 only in early March, and only in the 301 Bridge-Morgantown area, during a short period of density stratification of the water column. Stephanodiscus spp. formed more than $50 \%$ of the phytoplankton at Cobb Island and 301 Bridge in December 1980. Chaetoceros spp. dominated the phytoplankton of 301 Bridge and Cobb Island in February 1981 and at the 301 Bridge Station when it was unstratified in March. The diatom Rhizosolenia spp. bloomed in April.

Skeletonema spp., Chaetoceros spp. and Prorocentrum spp. were predominant at higher salinities at and downstream of Piney Point throughout the winter of 1980-81. Stephanodiscus spp and Prorocentrum spp. dominated in the same region in 1980. Rhizosolenia spp. exceeded $50 \%$ of the population during almost every sampling period in April and May 1981 (Cohen et al. 1984).

\section{Physical characteristics of the estuary and response of phytoplankton}

The water column in the 301 Bridge to Cobb Island reach was density-stratified throughout the winter of 1979-80. Fig. 3 is a typical salinity and temperature profile at 301 Bridge in March 1980. The estuary near 301 Bridge in the winter of 1980-81 was not stratified. Potomac River fresh-water discharge was high (mean discharge $=463 \mathrm{~m}^{3} \mathrm{~s}^{-1}$ ) in the $6 \mathrm{mo}$ (Jun through Nov) prior to the winter dinoflagellate bloom of 1979-80 but was low (mean discharge $=107 \mathrm{~m}^{3} \mathrm{~s}^{-1}$ ) in the same months prior to $1980-81$. There was little rainfall from December 1980 through March 1981 (13.6 cm for the period) compared to December 1979 through March $1980(25.2 \mathrm{~cm})$. Thus, the high input of low density water (dominated by fresh-water input from the tidal river) may have given rise to the stratification observed in 


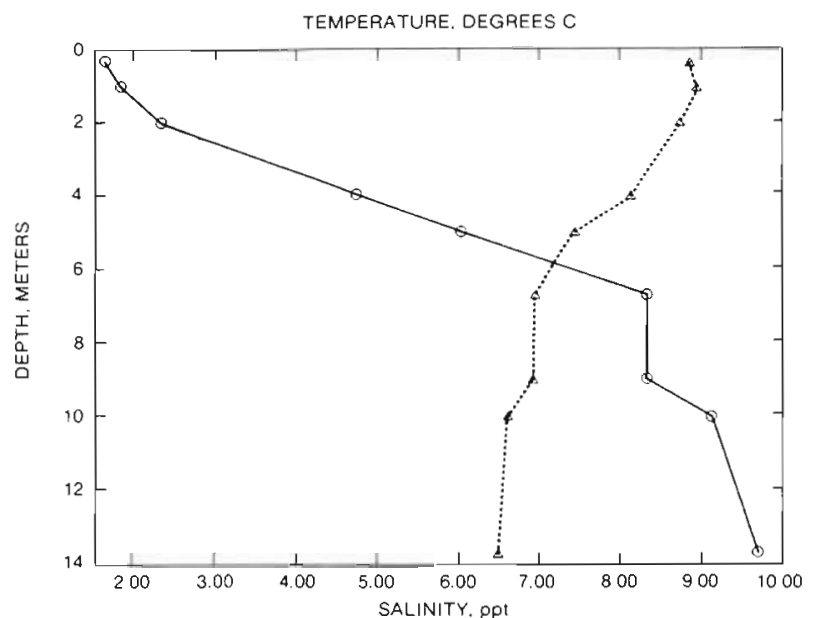

Fig. 3. Vertical profile of temperature $(\triangle)$ and salinity $(O)$ at 301 Bridge in March 1980

1979-80. Wind conditions were similar in the 2 winters except during March. March 1981 winds were stronger $\left(\right.$ mean $\left.=19.2 \mathrm{~km} \mathrm{~h}^{-1}\right)$ than those in March 1980 (mean $\left.=14.8 \mathrm{~km} \mathrm{~h}^{-1}\right)$.

Margalef (1978), Pingree et al. (1978), and Bowman et al. (1981) have presented diagrams that show an 'ecological space' for dinoflagellates and diatoms as a function of variables representing intensity of mixing (turbulence, diffusivity, water column stability) and a variable that directly controls growth rate (light, nutrients). When parameters indicating phytoplankton dominance are graphed, with the abscissa indicating levels of stability ( $E$ or sigma-t ratios) and the ordinate a value $k_{e} z$ (as in Bowman et al. 1981) where $k_{e}$ is the diffuse attenuation coefficient, diatoms and Katodinium rotundatum of the Potomac do not partition as suggested by Pingree et al. (1978) and Bowman et al. (1981). The value of $\mathrm{k}_{\mathrm{e}} \mathrm{z}$ varies more due to differences in station depths, $z$, than to attenuation coefficient, $k_{e}$. Although the Morgantown $(\mathrm{z}=20 \mathrm{~m})$ station was dominated by $K$. rotundatum in 1980 and diatoms in $1981, \mathrm{k}_{\mathrm{e}} \mathrm{z}$ varied less between these years (41.5 in 1980 and 35.1 in 1981) than between Morgantown and Cobb Island $(\mathrm{z}=7 \mathrm{~m})$ during the $K$. rotundatum red tide at both stations (Morgantown, $\mathrm{k}_{\mathrm{e}} \mathrm{z}=41.5$; Cobb Island, $\mathrm{k}_{\mathrm{e}} \mathrm{z}=11.8$ ). There was a $72 \%$ difference in $\mathrm{k}_{\mathrm{e}} \mathrm{z}$ between Morgantown and Cobb Island during the $K$. rotundatum bloom of 1980 of which only $18 \%$ can be accounted for by variations in $k_{e}$. Thus, a different 'ecological space' must be mapped for the winter red tides of the Potomac estuary.

The new 'ecological space' (Fig. 4) shows the physi-
Fig. 4. Three-dimensional plot showing temperature, salinity near the bottom, and ratio of sigma-t near the surface to sigma-t near the bottom, for samples where Katodinium rotundatum or diatoms were more than $50 \%$ of phytoplankton populations

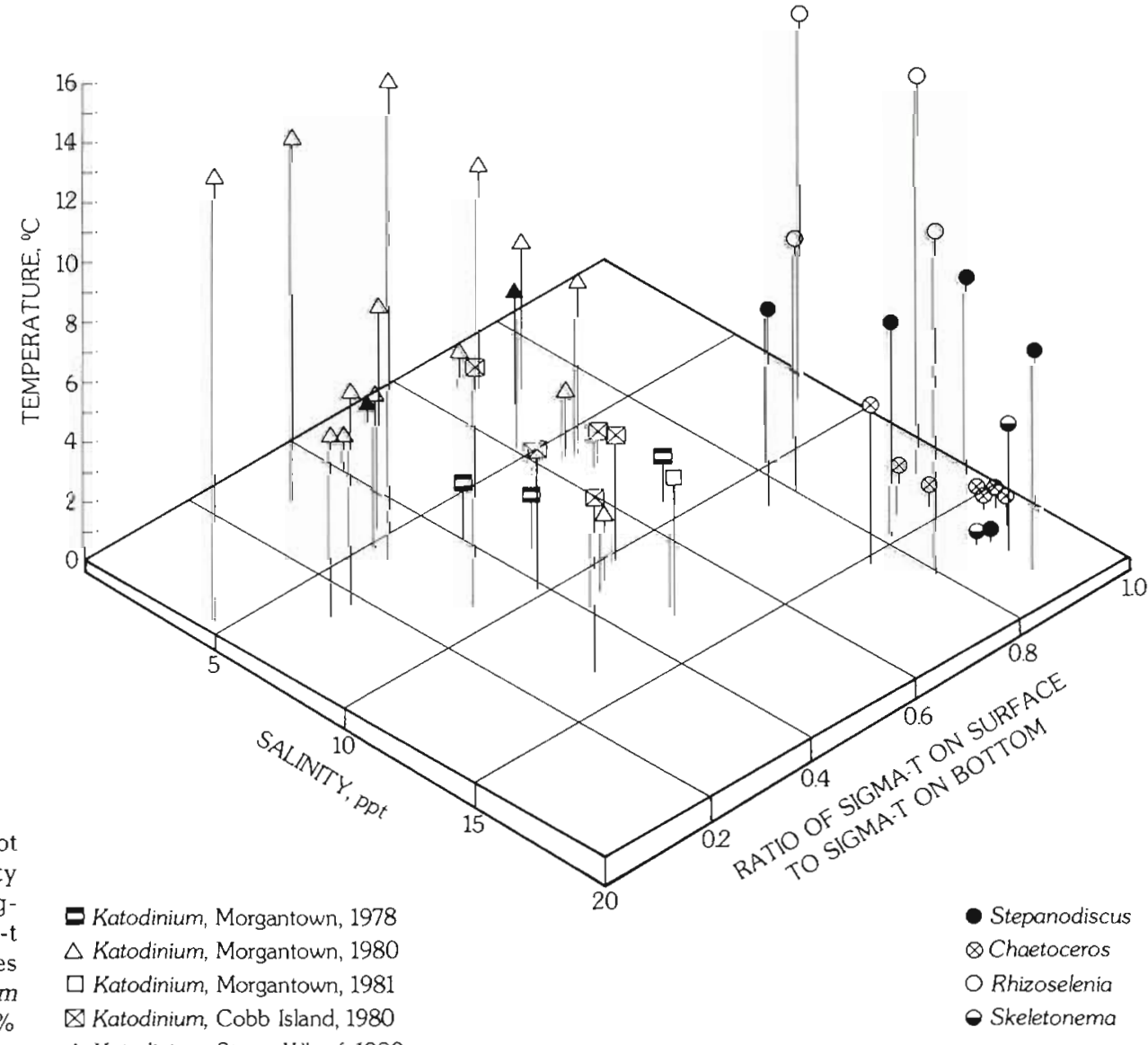


cal conditions - temperature, salinity near the bottom and the ratio of sigma-t near the surface to sigma-t near the bottom - in which Katodinium rotundatum and diatoms were observed during the winters of 1979-80 and 1980-81. Each symbol represents a sampling date in which a particular phytoplankton taxonomic group was $50 \%$ or more of the total population. The diatoms were located in a region bounded by sigma-t ratios of 0.8 and 1.0 and a salinity of $10 \mathrm{ppt}$ or more. K. rotundatum appears below a sigma-t ratio of 0.7 and below a salinity of $14 \mathrm{ppt}$. Included in the pattern are samples in which $K$. rotundatum exceeded $50 \%$ of the population in the Morgantown-301 Bridge reach on 3 March, 1981 (sigma-t ratio of 0.47 ) and in the Morgantown to Piney Point reach on 24 January, 1978 (sigma-t ratios below 0.7). The 1978 data are all labeled with the 'Morgantown 1978' symbol on Fig. 4.

The conceptual model developed in Fig. 4, that Katodinium rotundatum dominate in a stratified water column, was verified based on data reported by Cole \& Alpine (1980). A bloom of $K$ rotundatum was observed on 24 January 1978 between Morgantown and Piney Point. The estuary was stratified following 6 mo of high fresh-water inflow $\left(299 \mathrm{~m}^{3} \mathrm{~s}^{-1}\right)$. By 24 April 1978, the water column was completely mixed at Cobb Island with a sigma-t ratio of 1.0 . The estuary at Cobb Island was no longer dominated by $K$. rotundatum but by centric diatoms identified as Cyclotella spp. (which may be identical to the diatoms identified in 1980-81 as Stephanodiscus spp.).

\section{Vertical migration of Katodinium rotundatum}

One of the properties that permits dinoflagellates to flourish in a density-stratified water column is positive phototaxis (Dortch \& Maske 1982). Dinoflagellate motility can overcome thermal and density stratification and bring the organisms into the photic zone (Eppley et al. 1978, Smayda 1980). By migrating at night into the net upstream translation of the bottom waters and into the surface waters during the day, dinoflagellates can Inaintain their longitudinal position. Throndsen (1973) reported that Katodinium rotundatum were the fastest swimmers of 12 dinoflagellate species he studied: $15 \mathrm{~m}$ in $12 \mathrm{~h}$. Diatoms, however, are maintained in the photic zone by vertical mixing (Eppley et al. 1978, Smayda 1980).

There was evidence of vertical migration of Katodinium rotundatum. Fig. 5 shows the ratio of the percent composition of $K$. rotundatum on the surface to the percent composition near the bottom (mean for 4 stations $\pm \mathrm{SE}$ ). The ratio is highest at the noon sampling and is lowest at $0400 \mathrm{~h}$. The difference between any mean and those adjacent to it in sampling time is

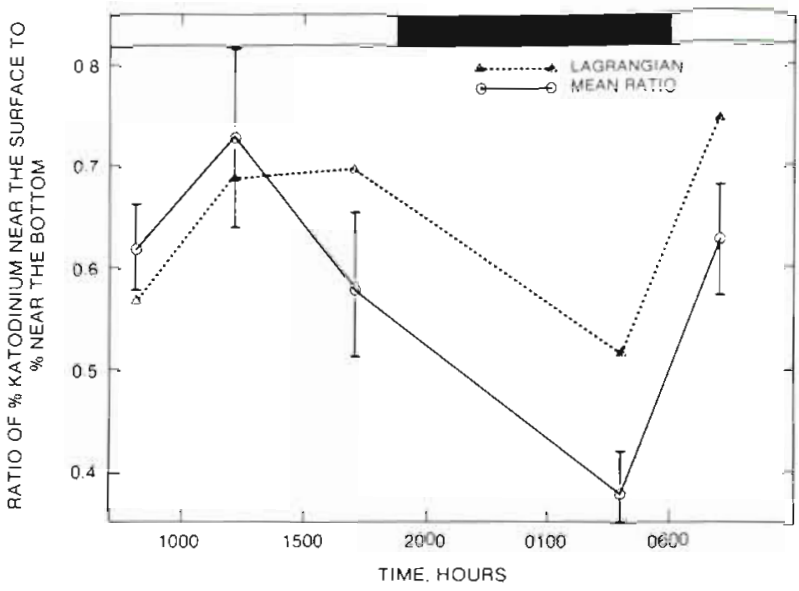

Fig. 5. Katodinium rotundatum. Ratio of per cent composition near the surface to per cent composition near the bottom. Solid line is the mean ratio for 4 stations, with standard error bars. Dashed line is results from following a parcel in a Lagrangian sense. Black bar at top represents darkness

significant at the 0.05 level. The ratio of the number of $K$. rotundatum on the surface to those on the bottom similarly increased from morning to noon and decreased to a minimum at $0400 \mathrm{~h}$ at each station.

The changes in the ratios of surface to bottom Katodinium rotundatum composition can be described in a 'Lagrangian' sense by examining, in an approximate way, the translation of a parcel of water over a tidal cycle. The $K$. rotundatum bloom was so sharply delineated at the fresh-brackish water interface that in situ fluorometry traces could be used to demonstrate the translation of the salt front over a tidal cycle. Fig. 6 shows longitudinal profiles of in situ fluorescence over a $24 \mathrm{~h}$ period. The location of the mininum concentration of chlorophyll over the sampling period shows the $5.6 \mathrm{~km}$ translation of the salt front over a tidal cycle (Fig. 6).

The tidal translation of the chlorophyll minimum calculated from Fig. 6 shows that a hypothetical water parcel at 301 Bridge moved approximately to buoy R32 during ebb tide and returned to 301 Bridge on the flood (Fig. 1b). The ratios of surface to bottom Katodinium rotundatum composition determined in this Lagrangian sense are shown in Fig. 5.

It was noted earlier that, by March, more Katodinium rotundatum were below the pycnocline than near the surface. Although vertical migration was evident, there was little change in the number of $K$. rotundatum below the density discontinuity over the day compared to the changes near the surface. If, during upward migration, recruitment is from below the pycnocline to above the pycnocline, then a net gain near the surface should be balanced by a loss of similar magnitude below the pycnocline. Fig. 7 shows that this is not the case (changes near the surface being at least double 


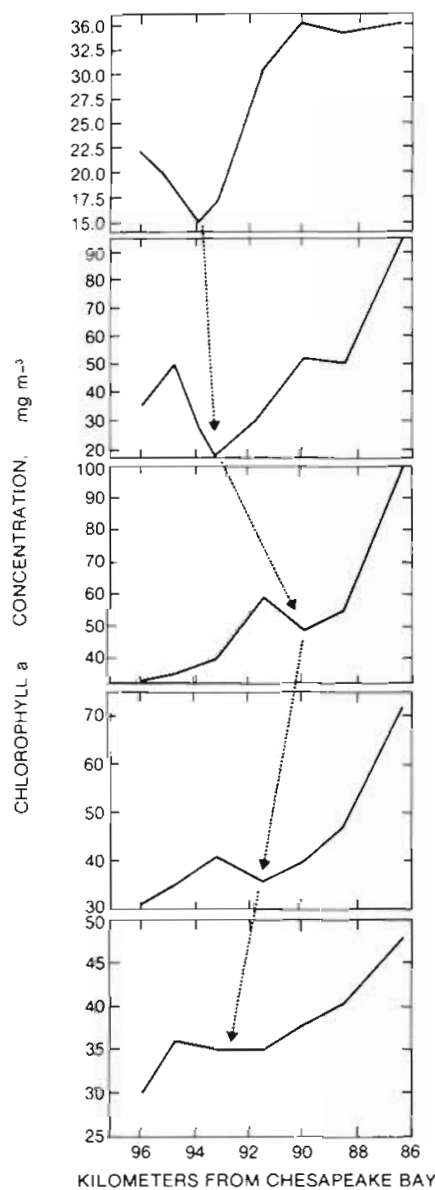

Fig. 6. Location of in situ chlorophyll a minimum at the brackish-freshwater interface over $24 \mathrm{~h}$ near the Morgantown station. Dashed lines and arrows point to location of the minimum to trace its motion. From the top, the sampling times are $0800,1200,1700$ on March 26, 1980, and 0500, 0700 on March 27

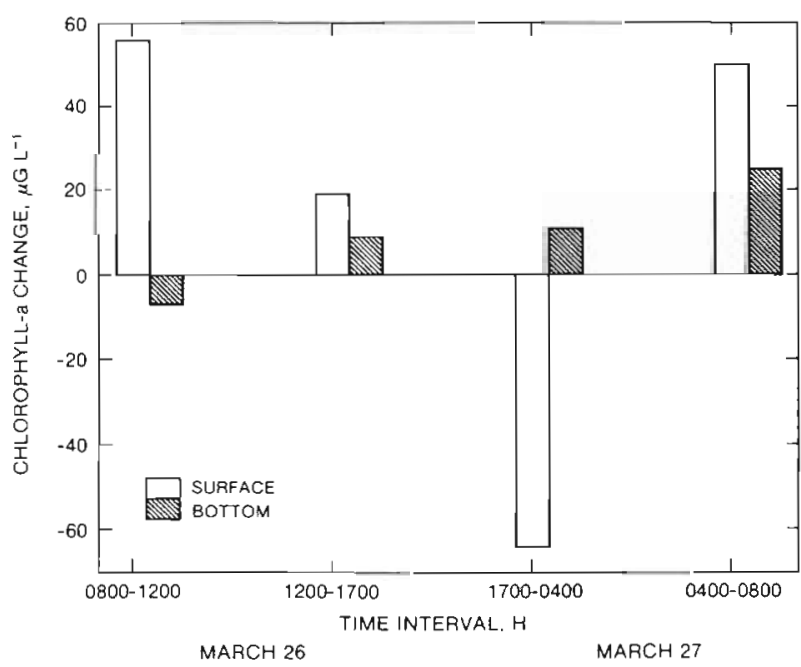

Fig. 7. Change of chlorophyll a from sampling period to period over $24 \mathrm{~h}$ following a parcel from buoys N2 to R32 to 301 Bridge to R32 and back to N2 those near the bottom), suggesting that the vertical migration was from the pycnocline to the surface. This is consistent with the findings of Tyler \& Seliger (1981) who reported that a steep density gradient may inhibit positive phototaxis through the pycnocline.

\section{Adaptation to low light levels}

Secchi depths were typically between 61 and $100 \mathrm{~cm}$ in March (60 to $75 \mathrm{~cm}$ during the March 26 and 27 vertical migration experiments), indicative of a euphotic zone (depth of $1 \%$ light) of approximately $2 \mathrm{~m}$. The pycnocline at 301 Bridge and Cobb Island was below $3 \mathrm{~m}$ (Fig. 3) and the depth was $15 \mathrm{~m}$. Thus, the Katodinium rotundatum that remained below the density discontinuity during the day existed at light levels below those considered to be compensation light intensities (Strickland 1958, Hobson 1966).

The Katodinium rotundatum appeared to respond as 'shade' algae (as defined by Ichimura et al. 1962, Tilzer \& Schwarz 1976). In 22 of 23 samples, the chlorophyll a per cell ratio in phytoplankton collected from below the pycnocline was higher than those from 1 to $2 \mathrm{~m}$ below the surface (Fig. 8). In addition, chlorophyll to cell ratios increased during the day and decreased at night, often by $300 \%$ or more (Fig. 8 ) as determined at 1 station (R32; Fig. 8), as a mean of 4 stations, and by following a parcel along the tidal excursion as discussed above.

\section{Nutrient conditions}

Nutrient conditions were similar in the winters of $1979-80$ and $1980-81$, both above and below the pycnocline. In 1980, the concentration of dissolved inor-

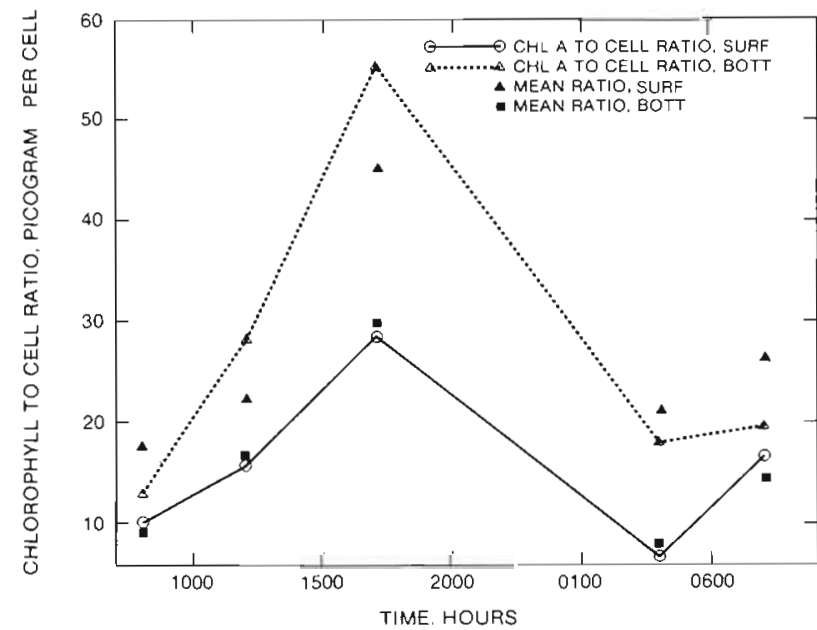

Fig. 8. Chlorophyll a to cell ratio at buoy R32, and mean for 4 stations, as a function of time, for above and below the pycnocline 
ganic nitrogen (as $\mathrm{N}$ ) ranged from 30 to $1500 \mu \mathrm{g} \mathrm{l}^{-1}$ and was typically 500 to $1000 \mu \mathrm{g} \mathrm{l}^{-1}$ from February through May with no tendency to be higher near the bottom. Concentration of dissolved organic nitrogen ranged from 60 to $1800 \mu \mathrm{g}^{-1}$ both near the surface and near the bottom. Dissolved phosphorus was 5 to $120 \mu \mathrm{g} \mathrm{l}^{-1}$, typically 10 to $20 \mu \mathrm{g} \mathrm{l}^{-1}$. In early 1981, inorganic nitrogen concentrations were similar to those in 1980. Up to mid-April, concentration of phosphorus was $>10 \mu \mathrm{g} \mathrm{l}^{-1}$ and that of organic nitrogen was 60 to $300 \mu \mathrm{g} \mathrm{l}^{-1}$ above and below the pycnocline. Nitrogen and phosphorus decreased to very low concentrations in late April.

\section{Source of Katodinium rotundatum seed stock}

The source of the Katodinium rotundatum bloom may have been a population that was transported upstream in the lower waters (as has been reported for a Prorocentrum sp. by Tyler \& Seliger 1978) or the $K$. rotundatum may have propagated in situ from resting stages. Cores taken in the summer of 1983 in the area of the 1980 and 1981 appearance of $K$. rotundatum did not give rise to a 'bloom'. However, a few specimens appeared at $12^{\circ} \mathrm{C}$ in the water above the sediment in 3 samples out of 41 samples examined over the period of incubation. A single individual was observed in each of the samples from Cobb Island and at N20 in the 0 to $2 \mathrm{~cm}$ depth core segment. The concentration of $K$. rotundatum cells calculated for each of the Cobb Island and N20 samples was $2 \times 10^{5} l^{-1}$ (out of a total of $8 \times 10^{5}$ and $1.6 \times 10^{6}$ cells $1^{-1}$, respectively). At $7^{\circ} \mathrm{C}$, another $K$. rotundatum cell was observed at a calculated $2 \times 10^{5}$ cells $l^{-1}$ out of a total $6 \times 10^{5}$ cells l$^{-1}$.

\section{DISCUSSION}

Eppley et al. (1978), Dortch \& Maske (1982), and many others have suggested that small flagellates, particularly dinoflagellates, dominate phytoplanktonic communities when water columns are density stratified. Diatoms predominate in well-mixed systems. The present results support these contentions. Katodinium rotundatum were predominant and present in high numbers when the Potomac Estuary was vertically stratified in January 1978 and December 1979 through March 1980. The source of the stratification was the large influx of low density water to the estuary. The completely mixed estuary of the 1981 winter was dominated by diatoms, except for a $2 \mathrm{wk}$ period when the water column was stratified. It was then dominated by $K$. rotundatum.

Katodinium rotundatum and diatoms did not parti- tion into an 'ecological space' - as presented as the Margalef mandala by Bowman et al. (1981) and Pingree et al. (1978). The value of $\mathrm{k}_{\mathrm{e}} \mathrm{z}$ varied more due to differences in station depth than to the depth of the mixed layer or to attenuation coefficients. $K$. rotundatum do, however, partition nicely using a 3-dimensional graph of salinity, temperature, and water column stability. The downstream, salinity-related limit of $K$. rotundatum may have been due to a frontal system located between Cobb Island and Piney Point and not to salinity intolerance. $K$. rotundatum has been found at salinities higher than $14 \mathrm{ppt}$ (M. Tyler pers. comm.).

One characteristic commonly cited to account for the success of phototactic dinoflagellates in stratified systems is the ability to gain access to the nutrient-rich bottom waters at night, then swim to the illuminated surface during the day (Eppley et al. 1968, Harrison 1976, Tyler \& Seliger 1978). Although dark uptake of nitrate has been demonstrated in dinoflagellates (Dortch \& Maske 1982), there is disagreement about the significance of the relation of vertical migration and dark uptake of nutrients (MacIsaac 1978, Cullen \& Horrigan 1981). In the Potomac Estuary, nutrient concentrations at Morgantown were high during the February through April periods of 1980 and 1981. There was no consistent pattern of higher nutrient concentrations near the bottom. Thus, vertical migration yielded no advantage for scavenging nutrients. It is possible that organic substances such as vitamins or complex carbohydrates reside below the pycnocline but they were not measured. The Katodinium rotundatum blooms seem to be determined by physical conditions temperature and vertical stratification. It cannot be ignored that the physical processes that induce stratification, such as fresh-water inflow, are also closely tied to the delivery of nutrients to the estuary.

Vertical migration, phased with 2-layer exchange, may account for the ability of dinoflagellates to maintain their horizontal downstream position (Seliger et al. 1975) (the upstream limit of $K$. rotundatum is defined by the fresh water/brackish water interface). It is obvious from the magnitude of the bloom that biological processes, such as growth for a 4 to 5 mo period, far exceed losses due to downstream transport. By March, when much of the bloom had settled to the bottom, the cells may have been protected from upstream and downstream losses by proximity to the lowest horizontal current velocities in the water column.

Katodinium rotundatum below the pycnocline were viable, even though light levels were less than $1 \%$ of the surface intensity. Tyler \& Seliger (1978) observed that Prorocentrum survived below a strong pycnocline even though light levels were very low. The $K$. rotun- 
datum were 'shade adapted' (Falkowski \& Owens 1980 ) by having 2 to 3 times higher chlorophyll-to-cell ratios than did surface samples.

There was a diel periodicity in Katodinium rotundatum cellular chlorophyll content. Riper et al. (1979) reported chlorophyll a turnover rates of 3 to $10 \mathrm{~h}$. LeBouteiller \& Herbland (1982) measured an increase of up to $200 \%$ over $1 \mathrm{~d}$. The increase of chlorophyll per cell during the day in $K$. rotundatum is equally dramatic.

The source of some dinoflagellates in the upper Chesapeake Bay is a population in the deeper waters of the lower bay (Tyler \& Seliger 1978). Potomac Katodinium rotundatum, on the other hand, are rarely observed at and downstream of Piney Point and at salinities above $14 \mathrm{ppt}$. Therefore, they probably arise, in situ, from resting stages in the sediment. Indeed, resting stages from benthic sediment collected in the bloom reach showed growth of $K$. rotundatum in the laboratory. I saw very few $K$. rotundatum cells arise from the incubated sediment, but the fact that any were seen at all demonstrates that the sediment can be a seed stock of $K$. rotundatum. Only a few cysts are required to seed a bloom. Steidinger \& Haddad (1981) calculated that 4 cysts $\mathrm{cm}^{-2}$ may seed $2 \mathrm{~km}^{2}$ with 25000 cells $1^{-1}$. This phenomenon was observed by Anderson et al. (1982) for several dinoflagellates in the Potomac Estuary.

The winter 1979-80 dinoflagellate bloom in the Potomac differs in some ways from others cited. First, it occurred during the coldest period of the year. Second, the conditions that gave rise to the red tide, a lowenergy, stratified water column and high nutrient concentrations, persisted for several months. Logical arguments by Margalef (1978) and Bowman et al. (1981) about the uniqueness and transience of these conditions are not applicable to the Potomac Estuary. Therefore, long-lived red tides of vertically migrating Katodinium rotundatum can be predicted to arise from the sediment during the winter when high fresh-water discharge has been observed in the previous summer and fall.

\section{CONCLUSION}

Winter blooms of Katodinium rotundatum have some properties similar to warm-season dinoflagellate blooms. $K$ rotundatum dominate during periods of stable density stratification of the water column; they manifest positive phototaxis, 'shade' adaptation, and diel periodicity of chlorophyll content. $K$. rotundatum arises from resting stages in the benthic sediment. The ecological limits of the bloom are defined by physical processes, particularly temperature and those that determine the extent of water column mixing.

\section{LITERATURE CITED}

Anderson, D. M., Aubrey, D. G., Tyler, M. A., Coats, D. W. (1982). Vertical and horizontal distributions of dinoflagellate cysts in sediments. Limnol. Oceanogr. 27: 757-764

Blanchard, S. F., Coupe, R. H. Jr., Woodward, J. C. (1982a). Water quality of the tidal Potomac river and estuary, hydrologic data report, 1980 water year. U.S. Geological Survey, Reston, Virginia, Open-File Report 82-152

Blanchard, S. F., Coupe, R. H. jr., Woodward, J. C. (1982b). Water quality of the tidal Potomac river and estuary, hydrologic data report, water year 1981. U.S. Geological Survey, Reston, Virginia, Open-File Report 82-575

Bowman, M. J., Esaias, W. E., Schnitzer, M. B. (1981). Tidal stirring and the distribution of phytoplankton in Long Island and Block Island Sounds. J. mar. Res. 39: 587-603

Cohen, R. R. H., Pollock, S. O., Stoelzel, V. A., Boulukos, K. E. (1984). Phytoplankton abundance and generic composition in the Potomac river and estuary, Maryland. U.S. Geological Survey, Reston, Virginia, Open-File Report 84-859

Cole, B. E., Alpine, A. E. (1980). Biological properties of the Potomac River Estuary: August 1977-August 1978. U.S. Geological Survey, Menlo Park, California, Open-File Report 80-343

Cullen, J. J., Horrigan, S. G. (1981). Effects of nitrate on the diurnal vertical migration, carbon to nitrogen ratio and the photosynthetic capacity of the dinoflagellate, Gymnodinium splendens. Mar. Biol. 62: 81-89

Cullen, J. J., Horrigan, S. G., Huntley, M. E., Reid, F. M. H. (1982). Yellow water in LaJolla Bay, California, July 1980. I. A bloom of the dinoflagellate Gymnodinium flavum. J. exp. mar. Biol. Ecol. 63: 67-80

Dortch, Q., Maske, H. (1982). Dark uptake of nitrate and nitrate reductase activity of a red-tide population off Peru. Mar Ecol. Prog. Ser. 9: 299-303

Eppley, R. W., Holm-Hansen, O., Strickland, J. D. H. (1968). Some observations in the vertical migration of dinoflagellates. J. Phycol. 4: 333-340

Eppley, R. W., Koeller, P., Wallace, G. T. (1978). Stirring influences the photoplankton species composition within enclosed columns of coastal seawater. J. exp. mar. Biol. Ecol. 32: 239

Falkowski, P. G., Owens, T. G. (1980). Light-shade adaptation: two strategies in marine phytoplankton. Pl. Physiol. 66: $592-595$

Hansen, D. V., Rattray, M. jr. (1966). New dimensions in estuary classification. Limnol. Oceanogr. 11: 319-326

Harrison, W G. (1976). Nitrate metabolism of the red tide dinoflagellate Gonyaulax polyedra. J. exp. mar. Biol. Ecol. 21: $199-209$

Hobson, L. A. (1966). Some influences of the Columbia river effluent on marine phytoplankton during January, 1961. Limnol. Oceanogr. 11: 222-234

Holm-Hansen, O., Riemann, B. (1978). Chlorophyll a determination: improvements in methodology: Oikos 30: 438-447

Ichimura, S., Saijo, Y., Argua, Y. (1962). Photosynthetic characteristics of marine phytoplankton and their ecological meaning in the chlorophyll method. Bot. Mag., Tokyo 75: $212-220$

Incze, L. S., Yentsch, C. M. (1981). Stable density fronts and dinoflagellate patches in a tidal estuary. Estuar. coast. Shelf Sci. 13: 547-556

LeBouteiller, A., Herbland, A. (1982). Diel variation of chlorophyll a as evidenced from a 13-day station in the equatorial Atlantic Ocean. Oceanologica Acta 5: 433-441

Lippson, A. J., et al. (1978). Environmental atlas of the 
Potomac Estuary. Environmental Center, Martin Marietta Corp., p. 74-83

Loftus, M. E., Subba Rao, D. V., Seliger, H. H. (1972). Growth and dissipation of phytoplankton in the Chesapeake Bay I. Response to a large pulse of rainfall. Chesapeake Sci. 13 282-299

MacIsaac, J. J. (1978). Diel cycles of inorganic nitrogen uptake in a natural phytoplankton population dominated by Gonyaulax polyedra. Limnol. Oceanogr. 23: 1-9

Margalef, R. (1978). Life forms of phytoplankton as survival alternatives in an unstable environment. Oceanologica Acta 1: 493-509

Neumann, G., Pierson, W. J. jr. (1966). Principles of physical oceanography. Prentice-Hall, Inc., Englewood Cliffs, New Jersey, p. 140-142

Pingree, R. D., Holligan, P. M., Mardell, G. T. (1978). The effects of vertical stability on phytoplankton distributed in the summer of the NW European shelf. Deep Sea Res. 25: 1011-1028

Prézelin, B. B., Matlick, H. A. (1980). Time course of photoadaptation in the photosynthesis-irradiance relationship of a dinoflagellate exhibiting photosynthetic periodicity. Mar. Biol. 58: 85-96

Riper, D. M., Owens, T. G., Falkowski, P. G. (1979). Chlorophyll turnover in Skeletonema costatum, a marine plankton diatom. Pl. Physiol. 64: 49-54

Rivkin, R. B., Seliger, H. H., Swift, E., Biggley, W. H. (1982). Light-shade adaptation by the ocean dinoflagellates Pyrocystis noctiluca and $P$. fusiformis. Mar. Biol. 68: 181-191

Ryther, J. H. (1965). Ecology of autotrophic marine dinoflagellates with reference to red water conditions. In: Johnson, F. H. (ed.) The luminescence of biological systems. A.A.A.S., Washington, D.C., p. 387-414

Seliger, H. H., Loftus, M. E., Subba Rao, D. V. (1975). Dino- flagellate accurnulations in Chesapeake Bay. In: Lo Cicero, V. R. (ed.) Toxic dinoflagellate blooms. Proc. Int. Conf (1st), Mass. Science Technol. Found, Wakefield, p 181-204

Skougstad, M. W., Fishman, M. J., Friedman, L. C., Erdmann D. E., Duncan, S. S. (1979). Methods for determination of inorganic substances in water and fluvial sediments. Techniques of water resources investigations, Book 5 . Chap. A1. U.S. Geological Survey

Smayda, T. (1980). Phytoplankton species succession. In Morris, I. (ed.) The physiological ecology of phytoplankton. Univ. of Calif. Press, Berkeley, p. 493-570

Steidinger, K. A., Haddad, K. (1981). Biologic and hydrographic aspects of red tides. Bioscience $31: 814-818$

Strickland, J. D. H. (1958). Solar radiation penetrating the ocean. J. Fish. Res. Bd Can. 15: 453-493

Strickland, J. D. H., Parsons, T. R. (1972). A practical handbook of seawater analysis (2nd ed.). Bull. Fish. Res. Bd Can. 167

Throndsen, J. (1973). Motility in some marine nanoplankton flagellates. Norw. J. Zool. 21: 193-200

Tilzer, M., Schwarz, K. (1976). Seasonal and vertical patterns of phytoplankton light adaptation in a high mountain lake. Arch. Hydrobiol. 77: 488-504

Tyler, M. A., Seliger, H. H. (1978). Annual subsurface transport of a red tide dinoflagellate to its bloom area: water circulation patterns and organism distributions in the Chesapeake Bay. Limnol. Oceanogr. 23: 227-246

Tyler, M. A., Seliger, H. H. (1981). Selection for a red tide organism: physiological responses to the physical environment. Limnol. Oceanogr. 26: 310-324

UtermöhI, H. (1958). Zur Vervollkommnung der quantitativen Phytoplankton-Methodik. Mitt. int. Verein. theor. angew. Limnol. 9: 1-38 